\title{
Tolstoilaisuudesta Johannes Linnankosken Pakolaisissa
}

\begin{abstract}
Suotuisa oli se vuoden 1908 elokuun puolivälistä lokakuun alkụun kestänyt luomiskausi, jolloin pitkän ulkomaanmatkan rasittama ja jo piilevän sairauden heikentämä Johannes Linnankoski kirjoitti talonpoikaistarinansa Pakolaiset. Vajaat kaksi kuukautta kestänyt ja helpolta vaikuttava luomisperiodi ei kuitenkaan ole suoraan verrannollisessa suhteessa teoksen taiteelliseen arvoon. Pakolaisten saamaa kirjallista arvostusta ovat todistamassa yksi akateeminen väitöskirja ja monet lyhyemmät arvioinnit, joissa teokselle suodaan sija romaanitaiteemme eturivissä. Linnankoskea käsittelevissä elämäkerrallisissa tutkimuksissa se taas varauksetta tunnustetaan tekijänsä suurimmaksi taiteelliseksi saavutukseksi. Sitä on analysoitu ja tulkittu, sen ansioita on seloștettu moneltakin kannalta, sen todellisuuspohja ja elävät esikuvat on löydetty ja heitä on verrattu kertomuksen eri henkilöihin. Linnankosken elämäkerran kirjoittaja Aarne Anttila on tarkoin merkinnyt muistiin Pakolaisten esikuvien vaiheet kirkonkirjoihin tukeutuen, mutta pitää tarpeettomana mennä liian yksityiskohtaiseen esittelyyn: "Olisi muuten toivottoman pitkää luetella kaikkia yksityispiirteitä, jotka kirjailija ilmeisesti ja suoraan on lainannut tämän hämäläisperheen tarinasta." ${ }_{1}$

Todellisuuspohjan liian voimakasta korostamista eivät liioin ole katsoneet aiheelliseksi Werner Söderhjelm, V. Tarkiainen, Rafael Koskimies; V. A. Koskenniemi, Leevi Valkama ja monet muut, jotka Pakolaisista ovat kirjoittaneet joko erikseen tai laajemmissa yhteyksissä. Jokainen heistä sen sijaan kiiruhtaa vakuuttamaan, että yksityis-
\end{abstract}

${ }^{1}$ Aarne Anttila, Vihtori Peltonen-Johannes Linnankoski. Elämä ja toiminta. II. Porvoo 1927, s. 213. 
kohtien uskottavan tarkasta kuvauksesta ja maalaisväestön erehtymättömästä tuntemuksesta huolimatta kertomuksen arvo on toisaalla. Riittäköön tässä Anttilan luonnehdinta: "'Pakolaisten' ydin, Uutelan sielunkamppailun kuvaus, ei voi luonnollisesti olla vain ulkokohtaisen huomioinnin tulosta. — — - Se käsky: vo it a its es i, jota Uutela itsetiedottomasti seuraa, on inhimillisen siveysopin suurimpia ja ikuisimpia, mutta samalla niin yksinkertainen, että se asettuu velvoittavana jokaisen eteen ja kutsuu taisteluun, sitä vaikeampaan, mitä voimakkaammat luonteen vaistot ovat ja mitä ankarampi on sen siveellinen vakavuus." 2

Tähän samaan kertomuksen ydinkohtaan, Uutelan sielunkamppailuun, ovat kaikki muutkin Linnankosken tutkijat pohjanneet Pakolaisten mittavuuden taiteellisena saavutuksena. Epäilemättä kertoja on itsekin antanut sille keskeisen tehtävän romaanin taloudessa; Uutelan taistelu jaloon itsensä voittamiseen, yhä suurempaan alistumiseen ja rauhaan vie kertomuksesta runsaan kolmanneksen, kun toisaalta sivuutetaan monia perheen vaiheita ja juonen kannalta tärkeitä yksityiskohtia, joita lukija joskus suorastaan jää kaipaamaan.

Uutelan sielullisen taistelun uljuutta ja hänen loputonta hyvyyttään on sovellettu myös kuvaajansa siveellisiin katsomuksiin. Linnankosken eettinen elämänvaatimus tuntuu kuitenkin enemmän sosiaalisen tarkoituksenmukaisuuden värittämältä kuin sielulliseen kirkastumiseen tähtäävältä. Tiettävästi ei ylssikään Pakolaisten tulkitsíjoista ole edes ohimennen huomauttanut Tolstoin mahdollisesta vaikutuksesta. Aivan ilmeistä näyttää kuitenkin olevan, että tolstoilaisuudella on oma osuutensa Uutelan hyvyyden evankeliumin toteuttamisessa ja vähittäisessä irtautumisessa kaikesta turhasta kunnianhimosta. Oliko se ehkä kirjailijan taholta tietoista? Kuinka paljon hän tunsi Tolstoin tuotantoa ja arvosti suuren venäläisen julistajan uudenlaista kristinopin tulkintaa?

Nämä kysymykset jäävät täsmällistä vastausta vaille, niin paljon kuin Linnankosken jäämistöstä onkin tutkijoiden käytettäväksi säilynyt. Tutkimus ei liioin ole kiinnittänyt vielä tarpeeksi huomiota Tolstoin vaikutukseen suomalaisessa kaunokirjallisuudessa. Ainoa mittava teos, Armo Nokkalan Tolstoilaisuus Suomessa, jättää tutkimuksen ulkopuolelle nimenomaan kaunokirjallisuuden lukuun otta-

${ }^{2}$ Aarne Anttila, Johannes Linnankoski. Oma maa 5. Porvoo 1924, s. 798. 
matta eräitä teoksia, jotka ilmestyessään olivat herättäneet julkisen mielipiteen huomiota. ${ }^{3}$ Mutta vaikka edellä tehtyihin kysymyksiin ei lähdemateriaalin perusteella voidakaan saada täyttä vastausta, eräät ilmeiset yhtymäkohdat tolstoilaisuuden ja Pakolaisten sisimmän sanoman välillä ansaitsevat vähäisen huomion.

Tarkiainen mainitsee vuosisadan alun uusromanttisen kirjallisuuden olevan kauttaaltaan pikemminkin esteettistä kuin eettistä - toki Tohannes Linnankoskea lukuun ottamatta. ${ }^{4}$ Nokkala taas saa aiheen oikaista Tarkiaista siinä, että nimenomaan Järnefeltin kiihkein tolstoilainen julistus osuu juuri tuohon aikaan. ${ }^{5}$ Yleisessä tietoisuudessa lienee Arvid Järnefelt niin hallitsevasti tolstoilaisuuden edustaja Suomessa, että kaikki muut ovat jääneet hänen varjoonsa. Hänen elämänkulkunsa, jonka hän itse ohjasi oppi-isänsä jälkiä myöten, herätti myös lukevan yleisön huomion. Linnankosken kohdalla voidaan siis todeta, että jos ei muuten niin ainakin Järnefeltin kautta hän on saanut tietoja. Tolstoin taiteen ja etiikan käsityksistä.

Mutta aivan näin hatariin olettamuksiin meidän ei ole pakko tyytyä. Tiedetään ainakin se, että Linnankoski on omalta lukemaltaan tuntenut Tolstoin tuotantoa ja ihaillut venäläistä kirjailijaa myös suurena ihmisenä. Todettakoon ensin, että suomalaiset lukijat saivat vuonna 1908 ensimmäisen Leo Tolstoin elämänvaiheitten kuvauksen. Eino Kaliman monografia ilmestyi siis samana ruonna kuin Pakolaiset. Kalima toteaa kirjassaan, että meillä Suomessa ovat Tolstoin uskonnollis-reformatoriset julkaisut hänen taidekirjallista tuotantoaan tunnetumpia. Kirjoittaja valittaa tätä eritoten siitä syystä, että Tolstoin suuruus taiteilijana on kaikkialla maailmassa tunnustettu, kun taas hänen filosofisessa ajattelussaan on löydetty epäämättömiä heikkouksia, vaikka ne eivät vähennäkään hänen arvoaan totuuden etsijänä. ${ }^{6}$ Kalima luettelee sitten ne Tolstoin muutamat taiteelliset teokset, jotka hiljan oli saatu suomen kielelle. Uskon-

a Armo Nokkala, Tolstoilaisuus Suomessa. Aatehistoriallinen tutkimus. (Väi* tösk.) Helsinki 1958, s. 7.

${ }^{4}$ Viljo Tarkiainen, Suomalaisen kirjallisuuden historia. Helsinki 1934, s. 251.

s Armo Nokkala, mt. s. 124.

- Eino Kalima, Leo Tolstoi. Helsinki 1908, s. 7. Vrt. myös G. H. von Wright, Tolstoi ajattelijana. Ajatus ja julistus. Suom. Jussi Aro. Porvoo 1961, s. 221. Wright viittaa mm. Turgenevin käsityksiin Tolstoin "filosofisista harharetkistä". 
nonfilosofiset suomennokset Kalima mainitsee selostaessaan asianomaisia kirjoja.

Linnankosken talonpoikaistarinan ilmestymisvuoteen mennessä Tolstoin uskonnonfilosofisia kirjoja olikin saatettu koko joukko suomen kielelle. Kristuksen opin henki ilmestyi vuonna 1894 Arvid Järnefeltin suomentamana, ja vuonna 1905 sama kääntäjä suomensi Evankeliumin, joka painettiin Amerikassa. Vuotta myöhemmin se sentään saatiin julkaista myös Suomessa. Samana vuonna ilmestyi Tunnustus. Vuonna 1907 olivat vuorossa Jumalallisesta ja inhimillisestä, Kuinka evankeliumi on luettava ja Mikä on uskoni. Vuonna 1908 saatiin suomeksi lisää Tolstoita, sekä kaunokirjallista että filosofista, mm. Mitä meidän siis on tekeminen. Näitä Linnankoski tuskin ehti tutkia, koska hänen alkuvuodesta alkanut ulkomaanmatkansa kesti aina kesäkuun puoliväliin asti ja sen jälkeen alkoivat käytännölliset puuhat perheen kokoamiseksi ja sijoittamiseksi. Vajaan kahden kuukauden kiihkeän luomisperiodin aikana lukuaikaa jäi tuskin tarpeeksi. Joka tapauksessa on runsaista käännöksistä päätellen todettava se, että Tolstoi oli muodissa, tai ainakin se, että hänellä oli joukko ihailijoita, jotka toimittivat hänen teoksiaan suomeksi. Linnankosken tapaiselta kirjojen ahnehtijalta tällainen ei saattanut jäädä vaille huomiota.

Linnankosken tarkoista muistiinpanoista saadaan tietää varsin paljon hänen työtavoistaan, harjoitelmistaan, lukuharrastuksistaan ja kirjanhankinnoistaan. Monet veljelle osoitetut nuoruusvuosien kirjeet kertovat siitä perusteellisuudesta, millä kirjallisuudesta kiinnostunut nuori mies tutustui ensin kotimaiseen kirjallisuuteen ja myöhemmin, opittuaan vieraita kieliä, Tolstoihin, Ibseniin ja Brandesiin. ${ }^{\top}$ Vuosina 1900-1903, jolloin kirjailija ystäviltäänkin salassa katosi Porvoosta ja asettui Karinaisiin vakaasti päättäen omistautua kirjalliselle elämäntyölleen, hän luki kymmeniätuhansia sivuja. Hänen tarkkana luettelona säilynyt lukusuunnitelmansa sisältää mm. Tolstoin Kristinopin hengen (tarkoittaa luultavasti Kristuksen opin henkeä, koska Kristillinen oppi ilmestyi vasta vuonna 1909) ja Renanin teoksen Jesu lefnad. ${ }^{8}$ Samoihin aikoihin Linnankoski kirjoittaa

7 Aarne Anttila, Johannes Linnankoski ja hänen "Pakolaisensa". Helsinki 1921 , s. 5 .

8 Aarne Anttila, Vihtori Peltonen ... II, s. 21. 
muistiinpanovihkoonsa: "Tosirunoilijan tulee olla profeetta." Profeettaan viittaa jo Tolstoin maine suurena näkijänä. Linnankoski toteaa muistiinpanoissaan myös, että "tarkka sielunelämän analyseeraus on runoudessa suuriarvoista". ${ }^{9}$ Edelleen saadaan Linnankosken mustakantisista muistiinpanovihkoista tietää, että hän vuonna 1905 oli maksanut kirjakauppaan 47:25 mk:n suuruisen laskun, johon sisältyi mm. "Decameron, Rousseau, Tolstoi ym..". ${ }^{10}$

Muistutuksia Tolstoin suuruudesta tulee myös ulkoapäin. Ilmari Kianto kirjoittaa 10.1.1907: "Ah, milloin meidän maassa nousee mies, joka, kuten Leo Tolstoi, lyö järjen kirkkaalla ruoskalla kaikkia viulun vinguttajia ympäri korvia, sellaisia viulun vinguttajia, joille ei tosi elämä mitään merkitse eikä ihmisen siveellinen tila ole korkeinta kauneutta?" 11 Kiannon kanssa Linnankoski vaihtaa myöhemminkin ajatuksia Tolstoista. Kirjoittaessaan Kiannon romaanista $P y h \ddot{a}$ viha, jonka voimakkaasti kontrastisesta vihasta ja rakkaudesta Linnankoski on kiinnostunut, hän mainitsee itsellään olevan samanlaisia kamppailuja. Myöhemmin hän palaa Pyhään vihaan: "Minä uskon, että Tolstoin työtapa on sama kuin Teidän: lähtö omista elämykșistä ja 'tunnustuksista' ja että ensi kirjoituksella siinä on ollut paljon mautonta ja ypi-yksilöllistä. Mutta kun Tolstoi sitten kirjoitti nuo 7--8 kertaansa, niin hän hioi pois kaiken muun paitsi yleisinhimillisen ja silloin siinä oli 'tunnustuksen' totuus, mutta samalla myös 'taiteen' totuus s.o. yleisinhimillisyys, kaikki suoraan, häiritsemättä, koskettavuus." ${ }^{12}$

Tästä saattaa helposti saada sen käsityksen, että Linnankosken ihailu Tolstoita kohtaan oli yksinomaan artistista. Samaan päädytään myös siinä luonnoksessa, jonka Linnankoski teki Pakolaisia suunnitellessaan. Hän pitää Tolstoita esikuvana: "Tolstoin suurta, syvää taidetta. Perin yksinkertaista." Mutta erillisille lapuille on vielä kirjoitettu, että tekijän päämäärä oli kaksinainen, yleisinhimillinen ja psykologinen: "Suurta elämäntragediaa ja elämän kauneutta. Kuinka

\footnotetext{
${ }^{9}$ Sama, s. 22. Vrt. myös Johannes Linnankosken luonnoskirja Muistiinpanoja ( $v: n 1901$ vaiheilta). SKSA (Suomalaisen Kirjallisuuden Seuran käsikirjoitusarkisto).

${ }^{10}$ Johannes Linnankosken tilivihko. Merkintä on tehty 22.10. SKSA.

1 Ilmari Kiannon kirje Johannes Linnankoskelle 10. 1. 1907. SKSA.

${ }_{12}$ Aarne Anttila, Vihtori Peltonen... II, s. 261. Vrt. myös Johannes Linnankosken kirjejäljennökset Пlmari Kịannolle 15.6.1908 ja 27.11. 1910. SKSA.
} 
ihminen itsensä kanssa kamppailee. Kärsii, oppii."13 Ihmisen kärsiminen ja kamppailu oli siis yhtä tärkeä kuin suureen yksinkertaisuuteen pyṛkiminen. Vielä Linnankosken sairauden viime aikoina rouva Linnankoski kertoessaan lukuharrastuksistaan ylisti Tolstoita ihmisen ymmärtäjänä: "Kyllä Tolstoi sentään on suuri ihmisen kuvaamisessa."14 Ester Linnankoski oli Tolstoin ihailija, eikä hänen mahdollista vaikutustaan ole syytä väheksyä. Hän oli ennen avioliittoaan ollut läheisessä ystävyyssuhteessa Tolstoin oppeihin positiivisesti suhtautuvan Yrjö Wichmanin kanssa. Rouva Linnankosken säilyneestä kirjeenvaihdosta tosin selviää, että hänen suhtautumisensa Tolstoihin vaihtui välillä arvostelevaksi asenteeksi. ${ }^{15}$ Puolison sairasvuoteelle lähetetystä kirjeestä kuitenkin näkyy, että hän jatkuvasti ihaili Tolstoita juuri ihmisen kuvaajana.

Tolstoin ja Linnankosken kirjailijapersoonallisuuksien välillä saattaa havaita joitakin yhteisiä piirteitä. Niinpä Ikuisen taistelun ensi luonnos on peräisin jo vuodelta 1891, jolloin nuori Vihtori Peltonen kävi ankaran sieluntaistelun aistillisuuden ja ehdottoman siveellisyyden ihanteen ristiriidoissa. Kaksikymmentä vuotta myöhemmin ilmestyneet Simson ja Delila sekä Jeftan tytär. olivat myös julistuksia yhä voimakkaammin eroottistuvaa elämänkäsitystä vastaan. ${ }^{16}$ Myös Tolstoille, joka kuvitteli olevansa askeetti ja hartaasti tavoitteli rauhaa päästäkseen kuluttavasta aistillisesta intohimostaan, hänen fyysillistä omistusta himoitseva rakkautensa vaimoon oli perin pulmallinen vielä hänen ollessaan kuusikymmentäyhdeksänvuotias. ${ }^{17}$ Linnankoskella oli edelleen sitä paremmat mahdollisuudet lnoda taideteos, mitä läheisemmäksi hän tunsi aiheen, mitä kiinteämmin hän voi lähteä omista elämyksistään tai välittömästi havaitusta todellisuudesta. ${ }^{18}$ Myös Tolstoilla oli tapana ottaa aiheita ja henkilökuvia lähimmästä ystäväpiiristään, jopa omasta perheestään. ${ }^{19}$

13 Sama, s. 211. Vrt. myös Johannes Linnankosken kirjallisia esitöitä. Kl. n: o A 8621. II. SKSA.

${ }^{14}$ Ester Linnankosken kirje Johannes Linnankoskelle 29. 11. 1912. SKSA.

15 Armo Nokkala, mt. s. 52. Vrt. myös Ester Drugg'in (Linnankosken) kirjeet Yrjö Wichmanille mm. 15. 8.; 12.9.; 27. 9. 1893. SKSA.

10 Matti Kuusi, Johannes Linnankoski (1869-1913). Johdanto Johannes Linnankosken Valittwihin teoksiin. Porvoo 1953, ss. VII ja XV.

${ }_{17}$ Cynthia Asquith, Kreivitär Tolstoi. Kuvaus Leo Tolstoin avioliitosta. Suom. Feidi Järvenpää. Jyväskylä 1961, s. 197.

19-Aarne Anttila, Johannes Linnankoski. Oma maa 5, s. 797.

${ }^{10}$ Cynthia Asquith, mt. ss. 60-62. 
Pakolaisia kirjoittaessaan Linnankoski sai tilaisuuden ilmaista myös rakkautensa maahan ja sen siunaukseen. Tässäkin lienee lupa nähdä heijastus tolstoilaisesta kiintymyksestä maatalousaskareihin ${ }^{20}$ ja pyrkimyksestä maanomistuskysymyksen ratkaisuun, vaikka Linnankoskella epäilemättä oli siitä omasta takaa vakiintunut käsityksensä. Hänhän itse oli sekä käytännön maanviljelijä että kansanvalistaja, joka kirjasillaan ja kirjoitelmillaan antoi neuvoja maanviljelykseen liittyvistä asioista. Hänen toimittamassaan sarjassa Kyläläisten kirjasia toimittaja itse käsittelee usein maanviljelystä ja siihen liittyviä elinkeinoja. Ajatus maan säilymisestä ja sen kasvuvoimasta oli hänelle niin rakas, että hän vielä kuolinvuoteellaan antoi neuvoja vaimolleèn kotitilan hoitoa koskevista kysymyksistä. ${ }^{21}$

Maa oli myös Uutèlalle elävään ihmiseen verrattava olento, joka lievitti sielunkipuja ja tuskaa. Uudessa asuinpaikassaan koti-ikävän kalvamana Uutela iskee auransa syyskohmeiseen maahan moninkertaisella innolla: "'On kuin Jumalan onni, että asiat ovat näin', ajatteli Uutela, 'että heti pääsee maahan käsiksi'." (s. 71.)22 Ja kun nuorta emäntää lähdetään viemään kaupunkiin, jotta koko perheen raiteiltaan suistanut lapsi syntyisi etäämpänä, Uutela puuhailee pellolla kuten tavallisesti. Hän koettaa karkottaa kaikki ajatuksensa pois tulevasta "perillisestään" ja turvautuu itsetiedottomasti maahan. "Kuinkahan monta surua näihin Suomen peltoihin onkaan haudattu?" (s. 132.) Hänestä tuntuu siltä, että maa on ikään kuin pyhä, suurella vaivalla ja hiellä lunastettu. Mutta se kätkee myös salaisuuksia. Thmiset sukupolvesta toiseen ovat haudanneet suuria surujaan muokkaamaansa peltoon. Linnankosken ensimmäinen elämäkerran kirjoittaja Werner Söderhjelm on kiinnittänyt huomionsa kenties korostetummin kuin kukaan muu siihen, että Uutelalle maa ei ole vain elon lähde, vaan myös kätkö, johon hiljaisuudessa on haudattu paljon suruja. ${ }^{23}$

Kun vastasyntynyt sitten tuodaan taloon; Uutela joutuu taas uuden kiusauksen eteen jo kerran itsensä voitettuaan. Hän on vähällä

so Sama, s. 105.

${ }^{21}$ Johannes Linnankosken kirjeet Ester Linnankoskelle mm. 30.5.; 6.6.; 9. 6. 1913. SKSA.

${ }_{22}$ Sitaatit ovat Pakolaisten toisesta painoksesta. Porvoo 1908.

${ }^{23}$ Werner Söderhjelm; Johannes Linnankoski. Suom. Helle Cannelin (Kannila). Helsinki 1919, s. 155. 
tehdä lopun elämästään, kun Hanna, kaiken hyvän ruumilllistuma, estää hänet; ". . hän hoiperteli — astui muutamia askeleita — kaatui suulleen — tarttui molemmin käsin ruohoon niin että sormet tunkeutuivat syvälle mättäiseen heinänjuuristoon — veti itsensä lujasti maahan kiinni — ruohon sisästä alkoi kuulua nyyhkytystä." (s. 142.) Eräs Tolstoin elämänonnen perusohje oli myös kiinteä yhteys maahan. Onhan tunnettua, että hän vain vaivoin viihtyi Moskovan-kodissa, jossa perhe lasten kasvatuksen takia myöhemmin paljonkin oleskeli. Talon isäntä pakeni milloin minkin tekosyyn varjolla rakkaaseen Jasnaja Poljanaan. Niinpä hän kirjassaan Mikä on uskoni (suom. 1907) selittää yhdeksi ensimmäisistä ja kaikkien tunnustamista onnen ehdoista sellaisen elämän, jossa ihmisen yhteyttä luontoon ei ole häiritty. Elämä maan, kasvien ja eläinten kanssa auringon valossa on sielunharmonian kannalta ensiarvoisen tärkeä. ${ }^{24}$ Kokonaan eri asia ja tässä yhteydessä turhan pitkälle asiasta poikkeava on Tolstoin maatalouspoliittinen katsomus, joka Linnankoskella osin oli sama, mutta kokonaan omapohjaisesta kokemuksesta kasvanut ja meidän oloihimme soveltuva.

Rakkaus maahan ei sellaisenaan pysty pelastamaan Uutelaa. Hän hautaa sinne surunsa, mutta anteeksiantoon ja itsensä voittamiseen se ei häntä auta. Kysymys on "aviomiehen kunniasta", jonka loukkaaminen on vaikeimmin voitettavissa, ja luultavasti vain mies pystyy kuvaamaan sen niin totisin äänenpainoin. Nuori nainen, joka on naitettu vastoin tahtoaan, on sen sijaan jätetty tyyten sivuun. V. A. Koskenniemi toteaa, että se tapa, millä Uutelan sieluntaistelu on kuvattu eri asteissaan hillittömästä raivosta ja epätoivosta resignaatioon ja itsekurin kautta hiljaiseen kirkastumiseen ja voittoon, on kauneimpia sivuja mitä kirjailija on kertomataiteeseemme jättänyt. Koskenniemi viittaa tässä yhteydessä Linnankosken omaan eettisen miehekkääseen persoonallisuuteen. ${ }^{25}$ Aarne Anttila näkee romaanin ydinajatuksen kehittelyssä, kärsimyksen kirkastumisessa ja sen vapauttavassa voimassa vuosisadan vaihteen viriävän uskonnollisuuden, mystiikan vaikutusta. ${ }^{26}$ Rafael Koskimies on taipuvainen

${ }^{24}$ Leo Tolstoi, Mikä on uskoni. Suom. K. W. Järnefelt. Kuopio 1907, s. 185.

${ }_{25}$ V. A. Koskenniemi, Johannes Linnankoski: "Pakolaiset." Kootut teokset VIII. Porvoo 1955, s. 296.

26 Aarne Anttila, Johdatus uudenajan kirjallisuuden valtavirtauksiin ja lähteitä niiden valaisemiseksi. Porvoo 1926, s. 458. 
selittämään tämän tavallista puhtaampaan moraaliseen sfääriin nousun edellisvuosisadan romanttisen ihanteellisuuden jäänteeksi. ${ }^{27}$ Uutela on kilvoittelunsa voitokkaassa lopussa jo tavallaan jenseits, jossa pelkkä luonnollinen elämä häipyy taka-alalle, ellei peräti olemattomiin. Mutta - niin kuin sanottu - Tolstoin mahdolliseen vaikutukseen ei heistä kukaan suoranaisesti viittaa. Kirjoittajat muistavat sen sijaan mainita Linnankosken oman eettisen peruslaadun ja taisteluasenteen. Se onkin läpikäyvänä teemana kirjailijan koko tuotannossa niin kuin hänen omassa elämässäänkin." ${ }^{2 s}$

Linnankosken tarkoitus oli siis eräältä osalta luoda kertomus siitä, "kuinka ihminen itsensä kanssa kamppailee. Kärsii, oppii." Fän asettaakin Uutelan eteen niin monta koettelemusta, että vain raudanlujalla tahdolla kirjan päähenkilö kääntää ne voitokseen. "Äpärä" ja "renki" kohoaa talolliseksi, kokoaa varallisuutta ja saa lähinaapuriensa kunnioituksen myös nuhteettomalla elämällään. Hän on läpeensä hyvä ihminen — huolenpito yltää pienimpiinkin eläimiin asti — eikä hän perusta tulevan elämän kaipuuta Raamattuun vaan käytännön hyvyyteen: "Mutta siihen minä sentään vahvimmasti luotan, että kun vaan ei tee koskaan vääryyttä, niin totta sitten täytyy hyvin päättyä." (s. 93.) Uutelan opit ovat jäyhän suomalaisen maamiehen, mutta samalla myös Tolstoin korkeimmaksi ihanteeksi asettaman vuorisaarnan eettisiä normeja.

Mutta hyvä ihminen juuri onkin altis ihmisten kavaluudelle. Naidessaan itseään paljon nuoremman naisen Uutela ei tunne kärsivänsä mitään vääryyttä, vaikka tietääkin saavansa tytön vain rahojensa takia. Mutta kun vaimo kostaa epämieluisan avioliittonsa koko perhettä häpäisevällä tavalla, Uutela joutuu kovan sieluntaistelun eteen. 'Hänen ensi tunteensa oli, että hänen pitäisi mennä ja kuristaa petturi sikiöineen." (s. 102.) Hänen raivonsa kohdistuu ympärillä oleviin esineisiin; rahit, korvot, penkit murtuvat raivostuneen miehen temmeltäessä pirtissä. Kuvaavaa on, että lempeä Hanna, josta Uutela myöhemminkin saa paljon lohtua, ei hänkään raamatunlauseilla pysty taltuttamaan raivoavaa miestä. Uutela ei jaksa käsittää, mitä tekemistä Jumalalla on tässä asiassa. "'Ja onko tämä nyt Jumalan tahdosta?', ajatteli hän taas. 'Mitä hän minusta tahtoo.'" (s. 111.) Pap-

\footnotetext{
${ }_{27}^{27}$ Rafael Koskimies, Elävä kansalliskirjallisuus. II. Helsinki 1946, s. 329.

${ }^{28}$ Aarne Anttila, Johannes Linnankoski ja hänen "Pakolaisensa", s. 11.
} 
piin hän ei liioin katso voivansa luottaa. "Kyllä se sentään saapi jäädä." (s. 112.) Tosin hänen mielessään häivähtää vanhalle maalaismiehelle ominainen ajatustapa, että nimenomaan nyt saatavissa olevat papit ovat liian nuoria näin arkaluonteisen asian auttajaksi. Mutta sitten kääntyy ajatus taas omaan sisäiseen taisteluun. "Taitaa olla vaan yksin selviteltävä — kun se on yksin kannettavakin." (s. 112.) Keskitalon raamatunlauseet tuntuvat etovilta. "Hän päätti vetää tuon Raamattua lukevan ketun kaikesta tilille." (s. 117.) Tolstoin piittaamatonta asennetta kirkonpalvelijoihin ja hänen lopullista välirikkoansa valtiokirkon kanssa tämä ei tietenkään suoranaisesti heijastele, mutta sisäisen selvittelyn tarve on epäämätön kummallakin.

Selvyyteen pääseminen käy Uutelalta hitaasti ja tuskallisesti. Tänään tuntuu tuska toisenlaisena kuin huomenna. Tänään on löytyvinään jokin selvyyteen Iupaava kajastus, huomenna on taas pimeää. Joskus välähtää mieleen Tolstoin pakenemisen halu: "Joskus hän mietti: jos eroaisin sovinnossa, sanaa sanomatta - jättäisin heille kaikki ja menisin omaa tietäni? Silloin tästä pääsisin ja löytäisin rauhan." (s. 123.) Tolstoin suuria elämänkatsomuksellisia kamppailuja ei voida suoraan verrata Uutelan vanhuuden vastoinkäymiseen, mutta alkavan sieluntaistelun kulku on vastaavanlainen: "Minulle alkoi tulla ensin neuvottomuuden hetkiä, sitten hetkiä, jolloin elämä ikäänkuin pysähtyi, ikäänkuin en olisi tiennyt, miten minun oli eläminen, mitä tekeminen ja minä jouduin ymmälle ja vaivuin epätoivoon. Mutta se meni taas ohitse ja minä jatkoin entistä elämääni. Sitten nämä neuvottomuuden hetket alkoivat uudistua yhä tiheämpään ja tiheämpään ja yhä samassa muodossa. Nämä pysähdykset ilmenivät aina samoissa kysymyksissä: mitä varten? Mitäs sitten tulee?"29

Uutelan tie kirkastukseen alkaa siitä, että hän tunnustaa itselleen omat itsekkäät pyyteensä. Hän oli halunnut nuoren vaimon vain sen takia, että sai näyttää ihmisille pystyvänsä sellaisen saamaan. Kipeiden taistelujen ja murrosten jälkeen hän havaitsee myös oman syyllisyytensä ja sen, että kukin vastaa tässä elämässä vain itsestään. "Kukin elää täydellisesti omaa elämätään, hairahtuu, nousee, katuu, kärsii — aina vain yksin." (s. 127.) Tämä on hänen sieluntaistelunsa

${ }_{29}$ Leo Tolstoi, Tunnustus. Suom. K! W. Järnefelt. Kuopio 1906, s. 18. 
ydin ja hän saa tyydytyksen sen löytämisestä. Ihmisen käsitys elämästä on niin monimutkainen, ja kuitenkin elämä itsessään on niin yksinkertainen. On pidettävä vain huolta itsestä ja vastattava omista teoista, siinä kaiken yksinkertaisuus. Tältä pohjalta lähtien myös anteeksianto on helppo, toistenkin on vastattava itsestään. Ensimmäinen ja aivan liikutukseen asti käyvä Raamatun opetus Tolstoille oli se Kristuksen oppi, jossa saarnataan rakkautta, nöyryyttä, alistumista, itsekieltäytymistä ja pahan kostamista hyvällä..$^{30}$ Myöhemmin hän tähdentää kerran toisensa jälkeen anteeksiannon suuruutta: "Kristus käskee: antamaan anteeksi kaikille. Antamaan anteeksi ei vaan: yhden kerran, ei seitsemän kertaa, vaan loppumattomasti. Rakastamaan vihollisia, tekemään hyvää vainoojille." ${ }^{11}$ "Kuinka monasti ihmiselle tehtäneekin vääryyttä, on hänen antaminen anteeksi, eikä suuttuminen, sillä taivaan valtakunta on mahdollinen ainoastaan siellä, missä anteeksi antamusta löytyy. Jollemme anna anteeksi, menettelemme velallisen tavoin." 32

Vaikein hetki Uutelan kohdalle tulee silloin kun lapsi tuodaan kotiin; se on aina lähellä, elävänä, hengittävänä, katselevana. Hän kuvittelee jo päässeensä kirkastuksessaan niin pitkälle, ettei pahinkaan voi haavoittaa. Mutta kun junan vihellys kuuluu, kärryt vierivät pihalle, lapsi on tulossa, hän on epätoivoissaan vähällä hukuttaa itsensä. Nuori Hanna on taas lähellä pelastamassa. Jumalaan vetoaminen ei tälläkään kerralla auta, se on Uutelasta vain tylsiä sanoja: Mutta tytön hyvyys vangitsee hänet paikoilleen juuri kun hän on hyppäämässä veneestä järveen. Ja kun pelätty kohtaaminen on ohi, koko perhe vaikenee vanhan miehen jalon anteeksiantamisen edessä. Keskitalon tekee mieli mennä Uutelan luo, langeta hänen kaulaansa ja sanoa: sinä olet kostanut pahan hyvällä — anna nyt vielä meillekin anteeksi! Mutta vielä tämänkin jälkeen Uutelassa välähtää koston ajatus tai pikemminkin opetuksen tarve. Hän jättää testamentistaan Keskitalon väen kokonaan pois. Mutta tämänkin viimeisen kiusauksen yli hän pääsee jo helposti. "Mikä maailman menojen ohjaaja minä olen?" (s. 160), välähtää Uutelan aivoissa kun hän repii kohtalokkaan paperin palasiksi. Näin hän on sieluntaistelussaan tullut

so Leo Tolstoi, Mikä on uskoni, s. 8 .

${ }^{31}$ Sama, s. 30.

32 Leo Tolstoi, Kristuksen opin henki. Suom. Arvid Järnefelt. Kuopio 1894, s. 49 . 
sille kirkastuksen asteelle, josta Tolstoin Kristuksen opin henki sanoo: "Ja isän tahto on, ettemme ketään kohtaan tunne sydämessämme vihaa." " 33

Uutela toteuttaa Tolstoin vakaumuksia siinäkin, ettei hän usko Raamatun sanan ketään pelastavan. Tosin kirjạn alkupuolella hänen mielestään Keskitalon puheensa lomaan kylvämät raamatunlauseet sopivat paikalleen, mutta lopulla nekin alkavat häntä tympäistä. $\mathrm{Ne}$ ovat vain ulkonaista hurskastelua. Hän kuvittelee kernaasti Keskitalonkin vielä ennen kuolemaansa oppivan, ettei Jumala ole raamatunlauseissa, vaan elämässä. Kuolinvuoteellaan hän sanoo vuosikausia sairastaneelle apelleen, joka vihjaa omaan kuolemaansa: "Minähän tässä taidan kypsempi olla." (s. 158.) Uutela ajattelee epäilemättä tuota raamatunlausehurskautta, joka ei johda todelliseen sielun puhtauteen. Hän itse tuntee olevansa valmis siirtymään rajan tuolle puolen kaikesta maallisesta vapaana, niin vapaana, ettei hän edes halua pappia kuolinvuoteelleen. Ei edes haudan paikka ole enää tuossa tilassa tärkeä: "Onhan yhdentekevää missä makaan." (s. 156.) Hän on iloinen myös siitä, ettei ole lähtenyt jakamaan omaisuuttaan, määräämään kokonaisen perheen elämästä oman tahtonsa mukaan. "Testamentti on kauhea asia" (s. 161), hän ajattelee. Maallisen omaisuuden täydellinen väheksyminen on sekin Uutelan kilvoittelun tiellä Tolstoin oppien mukaista. Aikaisemmin omaisuus oli ollut erityisen tärkeä ja tavoittelemisen arvoinen, juuri sen avulla hän oli tahtonut "näyttää ihmisille". Nyt hän ajattelee vain toisia. Nuoreen emäntäänkin hän suhtautuu vapaasti ja rauhallisesti. Lähimmäisten teot, ulkonaiset, näennäiset siteet, eivät merkitse mitään. Katkeruus on jalostunut lempeäksi, sädehtiväksi hyväntahtoisuudeksi. Uutela on löytänyt uuden rauhan omasta itsestään ja saavuttanut uuden eettisen puhtauden, hänestä on kasvanut traagisiin mittoihin yltävä homo ethicus. ${ }^{34}$

Alussa oli maininta Linnankosken pyrkimyksestä "yksinkertaiseen suuruuteen" Tolstoin tapaan. Pakolaisten tyylissä ei tarvitse kuitenkaan kiinnittää huomiota vain tähän päästäkseen tolstoilaisen aatteellisen kilvoittelun jäljille. Leevi Valkama on väitöskirjassaan todennut, että Pakolaisten tyylissä on huomattava erityisen tärkeänä

33 Sama, s. 25.

${ }^{34}$ Matti Kuusi, m. kirj. s. VIII. 
eettisen sanaston yleisyys, vaikka sen ei tietysti tarvitse todistaa kirjailijan tarkoituksellista sananvalintaa. Joka tapauksessa eettistä sanastoa kuten hyvä, paha, huono, puhdas, kunniallinen, nuhteeton, viaton on käytetty Pakolaisissa niin, että se liittyy läheisesti elämään ja sen eri tilanteisiin. Kohdassa, jossa Uutela raivoaa sekapäisen tavoin saatuaan tietää vaimon odottavan lasta, Valkama huomaa sanonnassa tyylin kannaltakin kaksinaisen luonteen, jonka voi kat. soa ilmentävän kertojan moralistin ja julistajan asennetta. ${ }^{35}$ Valkama on kuitenkin välttänyt korostamasta liikaa yksityisiä tilanteita ja todennut eettisen sanaston kertomuksen luonteen mukaiseksi. Kielen taiteellisessa hahmottumisessa tapahtuu suuntautuminen julistajan asenteen mukaiseksi. ${ }^{36}$ Tutkija ei tosin viittaa Tolstoihin ja myöntääkin, ettei nuistä päämääristä, jotka Linnankoski kertomustaan suunnitellessaan itselleen asetti, voi saada täydellistä käsitystä. ${ }^{37}$

Koska kirjailija juuri Pakolaisten syntyvaiheessa ihailee artistisessa mielessä Tolstoin suurta yksinkertaisuutta, venäläisen kirjailijan aatteelliset julistukset ovat jääneet tutkijoiltakin huomaamatta. Tosiasia sitä paitsi on, että Linnankoski itse perusolemukseltaan edusti samaa eettisyyttä, joka Tolstoille oli koko elämän mullistava maailmankatsomuksellinen ongelma. Jo Linnankosken taistelijanasenteen mukaista oli hyvän voitto pahasta. Mutta hänen suuri lukeneisuutensa ja hänen merkintänsä, jotka viittaavat Tolstoin tuntemukseen; Pakolaisten ilmestyminen monien Tolstoin-suomennosten läheisessä tuntumassa ja vaimon ihaileva suhtautuminen Tolstoin oppeihin eivät voi olla johtamatta ajatuksia siihen, että suuren venäläisen kirjailijan aatemaailmakin on ollut hänelle läheinen tai ainakin kunnioituksen ja arvonannon kohde. Siitä on osa siirtynyt Pakolaisten päähenkilön hahmottumiseen.

${ }_{35}$ Leevi Valkama, Tutkimus Johannes Linnankosken "Pakolaisten" tyylistä. (Väitösk.) Kokkola 1957, ss. 61-62.

36 Sama, s. 70.

3 Sama, s. 22. 


\section{Kerttu SaArenheimo: Tolstoy-like features in Linnankoski's "The Fugitives"}

One of the most significant works in Finnish literature, "The Fugitives", a peasant tale by Johannes Linnankoski, was ereated during the weeks of autumn in 1908. The central theme of the book is the struggle in the soul of old Juha Uutela which leads to forgiveness and interior transfiguration, on his learning that his much younger wife is expecting another man's child. Students of literature have found in the dense construction of the novel a Tolstoy-like simplicity, which the writer is known to have striven for. But the novel's fundamental message contains Tolstoy's ideas. Several of Tolstoy's religiophilosophieal works had been translated into Finnish at the turn of the century and we may assume that Linnankoski was familiar with them. Uutela's thoughts, while he is struggling for lucidity, peace and forgiveness, contain much of Tolstoy's interpretation of Christian doctrine. The central figure of the novel feels the injury to his honour as a husband more deeply than any of the blows he has hitherto suffered and the knowledge of it drives him to the brink of suicide, to passionate thoughts of revenge and the thought of running away. He manages, however, to overeome all these temptations and to "foregive, not only once, nor seven times, but without end", as Tolstoy says in his book "My religious beliefs". Uutela feels towards the end of the story that he has achieved such interior transfiguration that his death is like sliding away, like falling asleep.

Uutela's love of the earth is also an aspect of the Tolstoy-like world of his thoughts. He buries his sorrow and care while labouring to cultivate his fields. The soil is sacred to him; the earth vibrates with the pain of his forefathers cultivating bread for their children. "How many sorrows are buried in the Finnish fields", Uutela muses when he escapes to the fields from a family which has suddenly become a stranger to him. The author himself was also a farmer, who, like Tolstoy enjoyed the labours of the land.

There are numerous indications in the literary remains of Johannes Linnankoski that he knew Tolstoy's works, even though he does not mention the books by name. At the beginning of the century Tolstoy was such a well-known writer in Finland that his doctrines could not escape such a diligent reader as Linnankoski. Some of the great Russian writer's ideas have gone into the making of the main character in "The Fugitives". 